\title{
PENERAPAN MEDIA PEMBELAJARAN MATH MOBILE LEARNING UNTUK MENINGKATKAN KEMAMPUAN PEMECAHAN MASALAH SISWA KELAS IV
}

\author{
Nurul Nikmah, Ratri Rahayu, dan Nur Fajrie
}

Universitas Muria Kudus

Email: ratri.rahayu@.umk.ac.id

\section{Info Artikel}

Sejarah Artikel:
Diterima 23 Juni 2020
Direvisi 27 Oktober 2020
Disetujui 02 Novenber 2020

Keywords:

problem solving learning activities, math mobile learning

\begin{abstract}
This study aims are to determine the improvement of mathematical problem solving skills with the application of math mobile learning media. The study was conducted in fourth grade of SD 1 Pasuruhan Kidul Kudus in the academic year 2018/2019 with the number of students 19.

The research method used was the classroom action research method which lasted for two cycles, namely in cycle I and cycle II. Each cycle consists of planning, implementing, observing and reflecting. The independent variable in this study is math mobile learning media, while the dependent variable is the ability to solve math problems, student learning activities, and teacher teaching skills. Data collection techniques used in this study include observation, interviews, documentation and tests. This data analysis technique uses quantitative and qualitative data analysis.

The results of this study indicate that the increase is, (1) The average mathematical problem solving ability of students with the percentage of classical completeness $68.42 \%$ (enough) in the first cycle to $94.73 \%$ (good) in the second cycle, (2) Activities student learning has increased with a value of 64.48 less (need guidance) in the first cycle and 76.72 (good) in the second cycle. (3) The percentage of teaching skills of teachers has increased by a percentage of $71 \%$ (enough) in the first cycle and $80.5 \%$ (good) in the second cycle. Based on the results of research carried out in class IV SD 1 Pasuruhan Kidul Kudus, it can be concluded that through math mobile learning media can improve the ability to solve mathematical problems in the surrounding material and flat area, student learning activities and teaching skills of teachers in teaching and learning.
\end{abstract}

\begin{abstract}
Abstrak
Penelitian ini bertujuan untuk mengetahui peningkatan kemampuan pemecahan masalah matematika dengan diterapkannya media math mobile learning. Penelitian dilaksanakan di kelas IV SD 1 Pasuruhan Kidul tahun pelajaran 2018/2019 dengan jumlah siswa 19. Metode penelitian yang digunakan yaitu metode penelitian tindakan kelas yang berlangsung selama dua siklus yaitu pada siklus I dan siklus II. Masing-masing siklus terdiri dari perencanaan, pelaksanaan, pengamatan dan refleksi. Variabel bebas pada penelitian ini yaitu media math mobile learning, sedangkan variabel terikatnya yaitu kemampuan pemecahan masalah matematika, aktivitas belajar siswa, dan keterampilan mengajar guru. Teknik pengumpulan data yang digunakan dalam penelitian ini meliputi observasi, wawancara, dokumentasi dan tes. Teknik analisis data ini menggunakan analisis data kuantitatif dan kualitatif.

Hasil penelitian ini menunjukkan bahwa meningkat yaitu, (1) rata-rata kemampuan pemecahan masalah matematika siswa dengan persentase ketuntasan klasikal $68,42 \%$ (tinggi) pada siklus I menjadi 94,73\% (sangat tinggi) pada siklus II, (2) aktivitas belajar siswa mengalami peningkatan dengan nilai 64,48 kurang (perlu bimbingan) pada siklus I dan 76,72 (baik) pada siklus II. (3) persentase keterampilan mengajar guru mengalami peningkatan dengan persentase $71 \%$ (cukup) pada siklus I dan $80,5 \%$ (baik) pada siklus II. Berdasarkan hasil penelitian yang dilaksanakan pada kelas IV SD 1 Pasuruhan Kidul dapat disimpulkan bahwa melalui media math mobile learning dapat meningkatkan kemampuan pemecahan masalah matematika pada materi keliling dan luas bangun datar, aktivitas belajar siswa dan keterampilan mengajar guru dalam proses belajar mengajar.
\end{abstract}




\section{PENDAHULUAN}

Matematika merupakan salah satu displin ilmu yang dapat meningkatkan kemampuan berpikir dan beragumentasi Matematika memiliki peranan penting dalam penyelesaian masalah sehari-hari, dalam dunia kerja, serta memberikan dukungan dalam pengembangan ilmu pengetahuan dan teknologi (Rahayu 2016). Tujuan pembelajaran matematika agar siswa mampu dan terampil menggunakan matematika. Oleh sebab itu, matematika sebagai ilmu dasar yang harus dikuasai dengan baik oleh siswa, terutama sejak usia sekolah dasar. Dalam kurikulum 2013 pembelajaran matematika, diharapkan dapat meningkatkan kreatifitas pembelajaran serta berkontribusi dalam masyarakat, bangsa dan negara yang mampu membekali siswa dengan berbagai kompetisi baik dari segi sikap, pengetahuan, maupun keterampilan. National Council of Teachers Mathematic (NCTM) menjelaskan bahwa terdapat lima kemampuan utama dalam pembelajaran matematika yaitu pemecahan masalah matematis, komunikasi matematis, penalaran matematis, koneksi matematis, dan representasi matematis.

Kemampuan pemecahan masalah adalah komponen penting dari kurikulum matematik dn di dalamnya terdapat inti dari aktivitas mtematika sehingga kemampuan pemecahan masalah matematika dikalangan siswa perlu mendapatkan perhatian dalam pembelajaran (Nayazik 2015). Pembelajaran pemecahan masalah matematika perlu dikeambangkan sejak dini karena dapat membantu siswa memecahkan masalah seharihari di kehidupannya. Hal tersebut dikarenakan siswa dapat memperoleh pengalaman dalam menggunakan pengetahuan serta keterampilan untuk menyelesaikan soal yang tidak rutin, semakin sering berlatih memecahkan masalah matematika maka semakin banyak pengalaman yang diperoleh sehingga mendorog siswa untuk menjadi pemecahan masalah yang baik. Selaras dengan pendapat Malinda, dkk (2017) bahwa melalui pembelajaran pemecahan masalah matematika juga meminta siswa untuk melakukan penyelidikan secara langusng sehingga memiliki pengalaman nyata. George Polya (dalam Nisa, 2015) mengemukakan bahwa terdapat empat tahap dalam memecahakan masalah yaitu 1) memahami masalah, 2) menyusun rencana penyelesaian, 3) melaksanakan penyelesaian, 4) memeriksa kembali.

Pada dasarnya mata pelajaran matematika di jenjang pendidikan dasar kebanyakan siswa yang tidak menyukai mata pelajaran tersebut. Siswa beranggap bahwa pelajaran matematika materinya sulit dipelajari, serta guru yang mengampu pelajaran matematika kurang inovatif dalam menggunakan media dan model pembelajaran. Anggapan tersebut menyebabkan siswa takut untuk belajar matematika. Hal ini mengakibatkan hasil belajar siswa menjadi rendah. Rendahnya hasil belajar siswa ditentukan dari keterampilan guru mengajar dan aktivitas siswa selama proses pembelajaran, belajar akan efektif jika dilakukan dalam suasana yang menyenangkan. Oleh sebab itu, di dalam belajar siswa diberi kesempatan untuk merencanakan dan menggunakan cara belajar yang mereka senangi.

Berdasarkan hasil wawancara dan observasi dapat disimpulkan bahwa proses pembelajaran matematika dikelas IV masih berpusat kepada guru yang dilakukan guru dalam menyampaikan materi lebih sering menggunakan metode konvesional, sehingga materi yang dicerna oleh siswa kurang maksimal. Dalam penyajian materi guru hanya menggunakan buku paket dan tidak ada variasi lainnya menggunakan media ataupun model pembelajaran, sehingga aktivitas belajar siswa rendah. Siswa kurang menyukai pelajaran matematika karena mereka merasa kesulitan dalam berhitung dan mengerjakan soal cerita. Siswa beranggapan bahwa mata pelajaran tersebut menakutkan. Hasil observasi dan wawancara didukung dengan hasil tes prasiklus. Berdasarkan hasil nilai tes prasiklus yang dilakukan di SD 01 Pasuruhan Kidul menunjukan hasil belajar siswa kelas IV yang berjumlah 19 siswa dengan KKM yang ditetapkan di sekolah adalah 65. Dilihat dari perolehan hasil rata-rata klasikal siswa yang diperoleh 15,79 dan hasil rata-rata klasikal pada setiap indikator pemecahan masalah yang diujikan, kriteria pembelajaran matematika perlu bimbingan. Pada indikator memahami masalah 72,89 dengan predikat cukup, indikator menentukan rencana strategi pemecahan masalah 32,89 dengan predikat perlu bimbingan, indikator melaksanakan rancana pemecahan masalah 65,53 dengan predikat cukup, indikator mengecek jawaban yang diperoleh 33,95 dengan predikat perlu bimbingan. Hasil tersebut diperoleh siswa yang tuntas hanya 3 siswa dan 16 siswa masih di bawah KKM yang telah ditentukan pihak sekolah.

Berdasarkan permasalahan yang dialami di SD 1 Pasuruhan Kidul untuk mengatasi permasalahan tersebut salah 
satunya menerapkan media pembelajaran yang melibatkan siswa berperan aktif saat pembelajaran berlangsung yang nantinya dapat meningkatkan pemecahan masalah matematika. Media pembelajaran sebagai penunjang proses pembelajaran matematika. Muhsetyo (2014) menjelaskan bahwa media merupakan alat bantu dalam proses pembelajaran yang secara terencana dipersiapkan guru untuk menjelaskan bahan pelajaran, serta digunakan siswa untuk terlibat langsung dengan pembelajaran matematika. Adanya media pembelajaran memudahkan siswa dalam belajar, memberikan pengamalam konkrit, menarik perhatian, mengaktifkan indera siswa dan membangkitkan dunia teori dan realitanya (Herlianti, 2014). Hal tersebut sependapat dengan Rahayu (2018) mengatakan bahwa menciptakan pembelajaran yang menyenangkan tidak hanya menerapkan model dalam proses belajar mengajar, melainkan juga didukung dengan adanya media pembelajaran.

Media pembelajaran sebaiknya media yang interaktif, salah satu hal yang mendukung interaktivitas adalah penggunaan media. Media yang digunakan dapat diperoleh dimana saja yaitu salah satunya perkembangan teknologi. Dalam penggunaan media pada perkembangan teknologi adalah suatu tantangan tersendiri, dulu hanya menggunakan sarana buku pegangan atau LKS maupun buku paket dan alat tulis seadanya dirasa sudah memenuhi perlengkapan proses belajar mengajar, namun kini dengan penggunaan media pada perkembangan teknologi siswa dapat berinteraksi dengan dunia multimedia. Penggunaan multimedia telah terbukti dalam membantu proses pembelajaran matematika (Maharani dan Basir, 2016). Kemajuan teknologi informasi dan komunikasi mempunyai kemajuan sangat pesat. Kemajuan dalam bidang teknologi memberikan pengaruh terhadap kemajuan bidang lainnya seperti kebudayaan, ekonomi, pendidikan, dan sebagainya. Kemajuan dalam pendidikan salah satunya dengan proses pembelajaran yang tidak lagi berpusat pada guru, dalam hal ini guru bertindak sebagai fasilitator bagi siswa. Berbagai pembelajaran yang berimplikasi pada student centered learning telah dikembangkan oleh beberapa ahli. Hal ini guru harus mempunyai kreatifitas dan inovasi dalam pembelajaran, salah satunya menggunakan media pembelajaran yang memanfaatkan teknologi informasi.

Salah satu penggunaan media dalam perkembangan teknologi yaitu media yang berbasis gadget atau android. Dengan adanya penyajian isi materi pelajaran dan pemanfaatanya melalui perangkat mobile sistem operasi andorid yang ada di telpon pintar dan computer tablet, membuat media yang disajikan tidak membosankan dikarenakan ada unsur multimedia baik berupa gambar, tulisan, gerakan, ataupun suara yang membuat siswa senang dalam belajar dan paham dengan materi yang disampaikan (A'ayun dan Rahmawati, 2018). Adapun inovasi media pembelajaran yaitu memanfaatkan teknologi sebagai media dalah proses belajar mengajar yang dekat dengan kehidupan anak yang diberi nama media math mobile learning. Tampilan math mobile learning disajikan dalam Gambar 1 berikut.

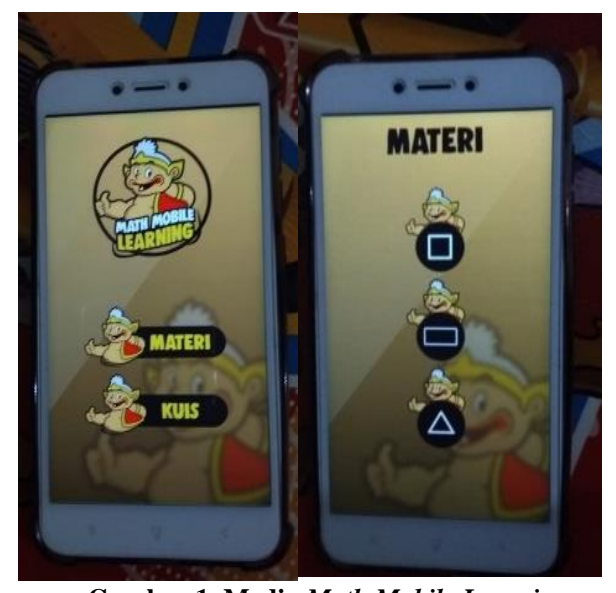

Gambar 1. Media Math Mobile Learning

Media pembelajaran math mobile learning merupakan sebuah media pembelajaran yang didesain dari aplikasi android sketchware, penggunaan media tersebut dengan cara menginstal aplikasi media math mobile learning di handphone. Mobile learning merupakan pembelajaran dengan perangkat Personal Digital Assistant (PDA), tab, iphone, dan HP sebagai device utama. Mobile learning dapat diaplikasikan dalam berbagai materi pembelajaran dalam jenjang pendidikan. Dengan demikian, mobile learning dapat digunakan dalam pembelajaran matematika baik jenjang pendidikan dasar, menengah, maupun jenjang perguruan tinggi. Disamping itu pembelajaran matematika akan terasa berbeda dengan menggunakan mobile learning dibanding dengan cara konvensional. Kelebihan dari media math mobile learning yaitu adanya aplikasi handphone yang tampilannya lebih menarik, dapat membuat siswa merasa antusias untuk mengikuti pelajaran dalam hal baru dan mengarahkan siswa dalam memahami konsep dan memecahkan masalah matematika. 


\begin{abstract}
Tujuan penelitian ini adalah mengetahui peningkatan kemampuan pemecahan masalah matematika dengan diterapkannya media math mobile learning.
\end{abstract}

\section{METODE PENELITIAN}

Penelitian tindakan kelas ini dilaksanakan di SD 1 Pasuruhan Kidul Kecamatan Jati Kabupaten Kudus, dengan subjek penelitian ini adalah siswa kelas IV semester II dengan fokus penelitian kemampuan pemecahan masalah matematika. Penelitian ini jenis penelitian yang digunakan adalah penelitian tindakan kelas yang mengacu pada model yang dikemukakan oleh Arikunto (2013). Penelitian dilakukan dalam dua siklus yaitu siklus I dan siklus II, pada tiap siklus meliputi empat tahapan yang saling keterkaitan yaitu: (1) Perencanaan (2) Pelaksanaan (3) Pengamatan (4) Refleksi. Adapun variabel bebas penelitian ini yakni media math mobile learning, sedangkan variabel terikat kemampuan pemecahan masalah matematika siswa, aktivitas belajar siswa, keterampilan mengajar guru.

Teknik pengumpulan data yang digunakan dalam penelitian ini yakni metode wawancara, obeservasi, tes, dan dokumentasi. Adapun instrumen yang digunakan yaitu lembar observasi aktivitas belajar siswa dan keterampilan mengajar guru dalam keterlaksanaan pembelajaran yang digunakan untuk melakukan pengamatan terhadap pembelajaran matematika melalui media math mobile learning. Analisis data kuantitatif digunakan untuk mengetahui digunakan untuk mengetahui peningkatan kemampuan pemecahan masalah matematika siswa kelas IV SD 1 Pasuruhan Kidul pada materi keliling dan luas bangun datar dengan diterapkannya media math mobile learning. Adapun kriteria ketuntasan belajar disajikan pada Tabel 1 . sebagai berikut.

Tabel 1. Kriteria Kemampuan Pemecahan Masalah Matematika

\begin{tabular}{cc}
\hline Nilai Siswa & Kriteria Ketuntasan Hasil Belajar Siswa \\
\hline$\geq 65$ & Tuntas \\
$<65$ & Tidak Tuntas \\
\hline \multicolumn{2}{c}{ KKM 65 }
\end{tabular}

Adapun rentang predikat kemampuan pemecahan masalah matematika dapat disajikan pada Tabel 2.
Tabel 2. Rentang Predikat Kemampuan Pemecahan Masalah Matematika

Rentang Nilai Predikat

$88<\mathrm{A} \leq 100 \quad$ (A) Sangat Baik

$76<\mathrm{B} \leq 88 \quad$ (B)Baik

$65<\mathrm{C} \leq 76 \quad$ (C)Cukup

$\mathrm{D}<65$

(D)Perlu Bimbingan

Perhitungan persentase ketuntasan belajar klasikal yang sudah diperoleh dapat dikategorikan ke dalam kriteria ketuntasan belajar klasikal siswa. Adapun kriteria tersebut disajikan pada Tabel 3.

Tabel 3 Kriteria Persentase Ketuntasan Belajar Klasikal

\begin{tabular}{cc}
\hline Persentase & Kriteria \\
\hline$>80 \%$ & Sangat Tinggi \\
$60-79 \%$ & Tinggi \\
$40-59 \%$ & Sedang \\
$20-30 \%$ & Rendah \\
$<20 \%$ & Sangat Rendah
\end{tabular}

Sumber: Aqib (2014:41)

Indikator keberhasilan pada penelitian ini adalah kemampuan pemecahan masalah matematika dengan menggunakan model STAD berbantuan media math mobile learning pada materi keliling dan luas bangun datar siswa kelas IV SD SD 1 Pasuruhan Kidul dapat mencapai nilai predikat cukup dengan kentuntasan belajar klasikal kriteria tinggi.

\section{HASIL DAN PEMBAHASAN}

Penelitian tindakan kelas ini diawali dengan kegiatan observasi dan wawancara dengan guru kelas IV di SD 1 Pasuruhan Kidul yang menunjukan informasi bahwa rendahnya proses pembelajaran matematika dikelas IV masih berpusat kepada guru yang dilakukan guru dalam menyampaikan materi lebih sering menggunakan metode konvesional, sehingga materi yang dicerna oleh siswa kurang maksimal. Dalam penyajian materi guru hanya menggunakan buku paket dan tidak ada variasi lainnya menggunakan media pembelajaran dalam menunjang proses belajar mengajar, sehingga aktivitas belajar siswa rendah. Siswa kurang menyukai pelajaran matematika karena mereka merasa kesulitan dalam berhitung dan mengerjakan soal cerita atau soal kemampuan pemecahan masaah. Siswa beranggapan bahwa mata pelajaran tersebut menakutkan. Peneliti menentukan tindakan untuk meningkatkan kemampuan pemecahan masalah matematika dengan menerapkan media pembelajaran sebagai penungjang proses belajar mengajar math mobile learning. 
Kegiatan siklus I dimulai dengan perencanaan yang meliputi penyusunan silabus, RPP, LKS, dan media untuk menunjang proses belajar mengajar, serta lembar observasi keterampilan mengajar guru dan aktivitas belajar siswa. Langkah kedua yaitu pelaksanaan tindakan dengan menerapkan media pembalajaran math mobile learning. Hasil ratarata kemampuan pemecahan masalah matematika siswa kelas IV siklus I dan siklus II dapat dilihat pada Tabel 4 sebagai berikut.

Tabel 4 Persentase Ketuntasan Belajar Siswa

\begin{tabular}{cccc}
\hline Tahap & $\begin{array}{c}\text { Tidak } \\
\text { Tuntas }\end{array}$ & Tuntas & Kriteria \\
\hline Siklus I & $31,58 \%$ & $68,42 \%$ & Tinggi \\
Siklus II & $5,27 \%$ & $94,73 \%$ & Sangat Tinggi \\
\hline
\end{tabular}

Tes kemampuan pemecahan masalah matematika diberikan sebanyak dua kali pada akhir siklus I dan siklus II. Hasil tes kemampuan kemampuan pemecahan masalah matematika mengalami peningkatan dari prasiklus ke siklus I dan ke siklus II. Peningkatan nilai rata-rata kemampuan pemecahan masalah matematika dari prasiklus sampai siklus II disajikan dalam Gambar 2 berikut.

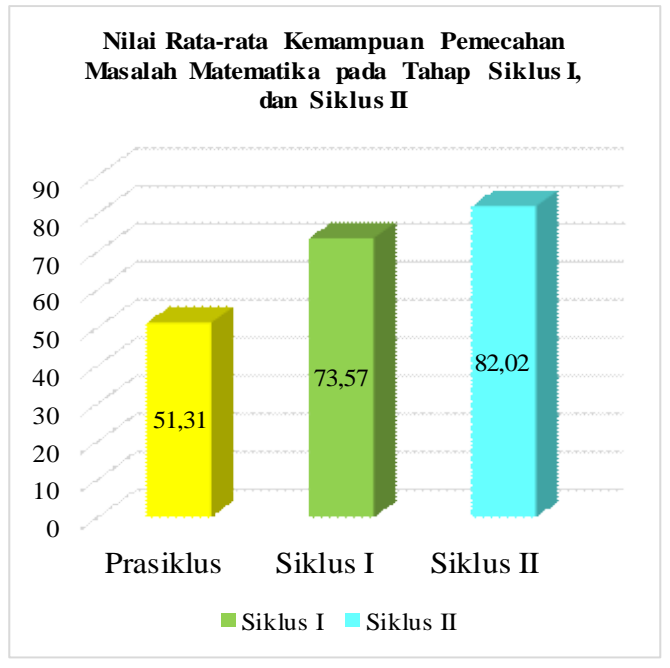

\section{Gambar 2. Peningkatan Kemampuan Pemecahan Masalah Matematika}

Kemampuan pemecahan masalah matematika siswa kelas IV SD 1 Pasuruhan Kidul setelah dilaksanakan pembelajaran menggunakan media math mobile learning, kemampuan pemecahan masalah matematika meningkat. Pada siklus I kemampuan pemecahan masalah matematika siswa memperoleh rata-rata 73,57 dengan predikat cukup, kemudian persentase belajar klasikalnya sebesar 68,42\% dengan kriteria tinggi.
Sedangkan pada siklus II rata-rata kemampuan pemecahan masalah matematika siswa mengalami peningkatan menjadi 82,02 dengan predikat baik, kemudian persentase ketuntasan belajar klasikalnya 94,73\% dengan kriteria sangat tinggi. Peningkatan tersebut dikarenakan materi keliling dan luas bangun datar disajikan dengan pendekatan diskusi kelompok dengan bantuan media math mobile learning untuk menyelesaikan masalah secara berkelompok dengan siswa berperan aktif dalam penyelesain masalah untuk menemukan jawaban yang tepat. Hal tersebut sejalan dengan pendapat Musa dan Nurhaidah (2017) yang mengatakan bahwa dengan adanya metode diskusi siswa mampu mengungkapkan atau berbicara mengenai ide, pendapat, atau opini serta berpasitipasi aktif dalam pembelajaran untuk menyelesaikan masalah.

Penggunaan media math mobile learning sangat mempengaruhi banyak aktivitas siswa. Ketika media tersebut ditunjukkan, siswa merasa tertarik, penasaran dan bertanya-tanya. Rasa penasaran dan tertarik tersebut termasuk dalam kegiatan emosional atau perasaan siswa. Selanjutnya siswa memperhatikan bagaimana penggunaan media math mobile learning dengan cara siswa mendengarkan, mengamati, dan melihat. Pada kegiatan tersebut siswa sudah mengalami kegiatan visual. Siswa diberi kesempatan untuk menggunakan media math mobile learning, seperti menyusun puzzle, menggambar bangun yang tersusun pada puzzle, dan menghitung setiap persegi satuan yang tersusun. Kegitan tersebut termasuk dalam kegiatan menggambar, mental, dan motorik siswa, karena siswa berpikir sambil melakukan.

Media math mobile learning pada prinsipnya mampu meningkatkan kemampuan masalah matematika siswa yang pada akhirnya berpengaruh pada hasil belajar siswa. Berdasarkan hasil penelitian yang telah diuraikan sebelumnya, dengan adanya inovatif media pembelajaran math mobile learning dapat meningkatkan kemampuan pemecahan masalah matematika siswa kelas IV SD 1 Pasuruhan kidul.Untuk memecahkan masalah ada empat langkah yang harus dilakukan, hal tersebut sesuai dengan pendapat Netrawati (2016) mengatakan bahwa untuk memecahkan masalah suatu terdapat empat langkah yang harus dilakukan, yaitu memahami masalah, menentukan rencana pemecahan masalah, melaksanakan rencana pemecahan masalah, dan mengechek jawaban yang diperolah. Adapun hasil peningkatan tiap indikator kemampuan pemecahan masalah matematika disajikan pada tabel berikut. 
Nurul Nikmah, Ratri Rahayu, dan Nur Fajrie

PENERAPAN MEDIA PEMBELAJARAN MATH MOBILE LEARNING UNTUK ....

WASIS: Jurnal Ilmiah Pendidikan. Volume 1, Nomor 2, November 2020, hlm. 1-8

Tabel 5 Nilai Rata-rata Tiap Indikator Pemecahan Masalah Matematika

\begin{tabular}{|c|c|c|c|c|c|}
\hline No & Indikator & $\begin{array}{c}\text { Rata-rata } \\
\text { Siklus I }\end{array}$ & Predikat & $\begin{array}{c}\text { Rata-rata } \\
\text { Siklus II }\end{array}$ & Predikat \\
\hline 1. & Memahami Masalah & 86,74 & (B) Baik & 87,16 & (B) Baik \\
\hline 2. & $\begin{array}{l}\text { Menentukan Rencana Pemecahan } \\
\text { Masalah }\end{array}$ & 48,21 & (D) Perlu Bimbingan & 69,05 & (C) Cukup \\
\hline 3. & $\begin{array}{l}\text { Melaksanakan Rencana } \\
\text { Pemecahan Masalah }\end{array}$ & 86,32 & (B) Baik & 88,21 & (B) Baik \\
\hline 4. & $\begin{array}{l}\text { Mengechek Jawaban Yang } \\
\text { Diperoleh }\end{array}$ & 61,26 & (D) Perlu Bimbingan & 70,53 & (C) Cukup \\
\hline
\end{tabular}

Pada indikator kemampuan pemecahan masalah matematika yang pertama yaitu indikator memahami masalah, siswa kelas IV SD 1 Pasuruhan Kidul pada tahap prasiklus memperoleh rata-rata 72,9 dengan predikat cukup. Pada siklus I rata-rata mengalami peningkatan menjadi 86 dengan predikat sangat baik, dan meningkat lagi pada siklus II menjadi 92 dengan predikat sangat baik. Hal ini dikarenakan siswa sudah mulai memahami masalah dan mengerjakan hampir semua soal yang diberikan. Hal tersebut sependapat dengan Aryani dan Riswanto (2017) yang menyatakan bahwa siswa yang termotivasi untu mempelajari sesuatu akan menggunakan proses kognitif yang lebih tinggi dalam belajar materi, sehingga siswa akan menyerap materi dengan lebih baik.

Indikator yang kedua yaitu menentukan rencana pemecahan masalah pada tahap prasiklus memperoleh nilai rat-rata 32,9 dengan predikat perlu bimbingan. Pada siklus I rata-rata mengalami peningkatan menjadi 58 dengan predikat perlu bimbingan, dan meningkat lagi pada siklus II menjadi 69 dengan predikat cukup. Upaya perbaikan yang dilakukan yaitu membimbing semua siswa untuk menentukan rencana pemecahan masalah sebelum melaksanakan penyelesaian. Siswa tidak langsung menulis jawabanya, tetapi siswa dibimbing dalam menentukan rencana pemecahan masalah. Hal tersebut sejalan dengan pendapat Sulaiman (2014) yang mengemukakan bahwa dalam peningkatan pemahaman siswa akan berhasil apabila disertai dengan kegiatan bimbingan kepada siswa. Indikator yang ketiga yaitu melaksanakan rencana pemecahan masalah pada tahap prasiklus memperoleh nilai rata-rata 65,5 dengan predikat cukup. Pada siklus I mengalami peningkatan rata-rata sebesar 89 dengan predikat sangat baik. Pada siklus II mengalami peningkatan menjadi 96 dengan predikat sangat baik, tetapi ada satu siswa yang belum tuntas. Siswa tersebut tidak tuntas dikarenakan belum menggunakan cara yang sistematis. Hal ini diakibatkan perencanaan penyelesaian masalah yang kurang tepat, mereka belum menyelesaikan masalah secara runtut sesuai langkah-langkah dalam pemecahan masalah. Upaya perbaikan yang dilakukan yaitu memberikan arahan kepada siswa untuk lebih teliti dalam menyelesaikan masalah, siswa diarahkan untuk meneliti lagi dalam melaksanakan rencana pemecahan masalah untuk mencegah kekeliruan dan kesalahan pada soal yang dikerjakan. Hal tersebut sejalan dengan pendapat Purbaya (2016) bahwa dengan adanya pengarahan atau bimbingan agar siswa mampu menguasai pengetahuan dan dapat mengembangkan keterampilan yang diperoleh.

Indikator yang keempat yaitu mengechek jawaban yang diperoleh, pada tahap prasiklus memperoleh nilai rata-rata 33,9 dengan predikat perlu bimbingan, pada siklus I mengalami peningkatan nilai rata-rata menjadi 60 dengan predikat perlu bimbingan, pada siklus II mengalami peningkatan menjadi 73 dengan predikat cukup siklus II sudah mengalami peningkatan. Upaya perbaikan yang dilakukan yaitu membimbing siswa untuk lebih jeli dalam memecahkan masalah yang berupai soal uraian. Siswa dibimbing untuk mengechek kembali langkah penyelesaian masalah dan hasil yang sudah dilakukan, agar tidak terjadi kesalahan. Hal tersebut sependapat dengan Mansur (2016) mengemukakan bahwa guru harus terampil dalam menyajikan atau menjelaskan materi secara runtut dan menggunakan kalimat bahsa yang baik dan benar agar memudahkan siswa memahamai penyelesaian masalah dengan baik.

Berdasarkan uraian peningkatan kemampuan pemecahan masalah matematika siswa, dapat disimpulkan bahwa kemampuan pemecahan masalah matematika siswa dengan menerapkan media math mobile leraning berhasil melampui indikator keberhasilan yang telah ditetapkan yaitu dengan 65 predikat 
cukup. Hal ini dapat dibuktikan dari data yang diperoleh baik melalui hasil observasi, hasil tes.

Peningkatan tersebut dikarenakan materi keliling dan luas bangun datar disajikan dengan pendekatan diskusi kelompok untuk menyelesaikan masalah secara berkelompok dengan siswa berperan aktif dalam penyelesain masalah untuk menemukan jawaban yang tepat melalui media math mobile learning. Hal tersebut didukung oleh pendapat A'ayun dan Rahmawati (2018) yang menjelaskan bahwa dengan menerapkan media pembelajaran berbasis android atau media math mobile learning dalam pembelajaran dapat memungkinkan siswa termotivasi dan antusias dalam mengikuti pembelajaran, membantu siswa memahami materi, membangkitkan minat belajar siswa. Diantoro, dkk (2020) juga menyampaikan bahwa penggunaan aplikasi dalam pembelajaran menjadikan siswa lebih tertarik dengan pembelajaran yang disampaikan oleh guru. Kekurangan dari media math mobile learning belum terdapat materi pembelajaran yang disampaikan dan medianya kurang interaktif.

Berdasarkan hasil pelaksanaan tindakan pada siklus I dan siklus II, pengamatan peneliti dan hasil observasi melalui lembar observasi dan diskusi, maka peneliti dapat menarik kesimpulan sebagai berikut: (1) berdasarkan hasil oberservasi kemampuan pemecahan masalah matematika pada siklus II siswa mengalami peningkatan pada siklus I, dan rata-rata tiap indikator kemampuan pemecahan masalah matematika sudah mencapai ketuntasan; (2) hasil belajar kemampuan pemecahan masalah matematika pada siklus II dapat dilihat dari jumlah siswa yang tuntas dalam tes siklus II, yaitu sebanyak 17 siswa dari 19 siswa kelas IV sebesar 94,73\%; (3) secara umum, siswa mengikuti proses pembelajaran dengan baik, siswa lebih aktif, dan berani bertanya kepada guru maupun teman sekelompok diskusi.

Pada akhir siklus II guru sepakat untuk memberhentikan penelitian, dengan alasan bahwa indikator keberhasilan sudah tercapai yaitu rata-rata kemampuan pemecahan masalah matematika siswa telah mencapai predikat baik, keterlaksanaan media math mobile learning, adanya peningkatan aktivitas belajar siswa dan keterampilan mengajar guru. Hasil tes menunjukkan adanya peningkatan kemampuan pemecahan masalah matematika siswa dengan media math mobile learning.

\section{SIMPULAN}

Berdasarkan hasil penelitian tindakan kelas yang dilakukan di SD 01 Pasuruhan Kidul, maka dapat disimpulkan bahwa penerapan media math mobile learning dapat meningkatkan kemampuan pemecahan masalah matematika siswa. Peningkatan kemampuan pemecahan masalah matematika siswa dapat dilihat dari meningkatnya nilai rata-rata kelas dan persentase ketuntasana belajar klasikal. Pada tahap pada tahap siklus I memperoleh nilai rata-rata 73,57 , dengan predikat cukup, dan persentase ketuntasan belajar klasikal memperoleh persentase $68,42 \%$ dengan kriteria tinggi. Sedangkan pada siklus II memperoleh nilai rata-rata 82,02 dengan predikat baik dan memperoleh persentase ketuntasan belajar klasikal 94,73\% dengan predikat sangat tinggi. Dengan demikian, kemampuan pemecahan masalah matematika telah mencapai indikator keberhasilahan yang telah ditentukan yaitu $\geq$ 65.

\section{DAFTAR PUSTAKA}

A'yun, N.Q dan Rahmawati, I. (2018). Pengembangan Media Interaktif $\mathrm{Si}$ Pontar Berbasis Aplikasi Android Materi KPK dan FPB Mata Pelajaran Matematika Kelas IV SD. Jurnal Pendidikan Guru Sekolah Dasar, 6 (2)

Aqib, Z. Et al. 2014. Penelitian Tindakan Kelas. Bandung: CV Yrama Widya

Arikunto, Suharsimi. 2013. Dasar-dasar Evaluasi Pendidikan. Jakarta:Bumi Aksara

Aryani, S., \& Riswanto, A. 2017. Learning Motivation And Student Achievement: Description Analysis And Realitionships both. The International Journal Of Counseling And Education, 2 (1)

Diantoro, C. T., Ismaya, E. A., \& Widianto, E. (2020). Peningkatan Hasil Belajar Siswa Melalui Model Quantum Teaching Berbantuan Media Aplikasi Edmodo Pada Siswa Sekolah Dasar. WASIS: Jurnal Ilmiah Pendidikan, 1(1), 1-6.

Herlianti, Yanti., dkk. 2014.'Penggunaan Media Pembelajaran Di Madrasah Aliah 
Negeri Se-Jakarta Selatan". Jurnal Edusains , 6(1): 68-72

Maharani H.R., \& Basir M.A. 2016. Pengembangan Media CD Interaktif Matematika Untuk Meningkatkan Kemampuan Pemecahan Masalah Siswa SMP. Jurnal Refleksi Edukatika, 7(1): 32-35

Malinda Z.A., Murtono, \& Zuliana E. 2017. Problem Based Learning Berbantuan Lego Meningkatkan Pemecahan Masalah Siswa Sekolah Dasar. Jurnal Refleksi Edukatika, 8(1), 66-73.

Mansur, Nurdin. 2016. "Penerapan Keterampilan Mengajar Dalam Upaya Pencapaian Hasil Belajar Mahasiswa". Jurnal Lantanida, 4(2): 118-127

Muhsetyo Gatot. 2008. Pembelajaran Matematika SD. Jakarta: Universitas Terbuka

Musa, I.M., \& Nurhaidah. 2017.Melalui Metode Diskusi Kelompok Dapat Meningkatkan Motivasi Belajar Siswa Pada Bidang Studi Matematika Materi Kelipatan Persekutuan Terkecil (KPK) Di Kelas IV SD Unggul Lampeuneurut Kabupaten Aceh Besar". Jurnal Pesona Dasar, 5(2): 78-92

Nayazik, Ahmad. 2017. Pembentukan keterampilan pemecahan masalah melalui model IDEAL problem solving dengan teori pemrosesan informasi. Jurnal matematika kreatif dan inovatif, 8(2):182-190
Netrawati. 2016. Analisis Kemampuan Pemecahan Masalah Matematis Berdasarkan Teori Polya Ditinjau Dari Pengetahuan Awal Mahasiswa IAIN Raden Intan Lampung. Jurnal Pendidikan Matematika, 7 (2): 181-190

Nisa, I. C. 2015. Pemecahan Masalah Matematika. Mataram: Duta Pustaka Ilmu

Purbaya, P.A., \& Fiah, E.R. 2016. Penerapan Bimbingan Belajar Dalam Meningkatkan Hasil Belajar Peserta Didik Di SMP Negeri 122 Kota Bandar Lampung Tahun Pelajaran 2015/2016. Jurnal Bimbingan dan Konseling, 03 (2): $230-244$

Rahayu, R., Kanzunnudin, M., \& Yuliana, I. 2018. Penerapan Model Creative Problem Solving Berbantuan Media Bongkar Pasang Untuk Meningkatkan Berpikir Kreatif Matematika. Jurnal Ilmiah Pendidikan Matematika,1(1): 3036

Rahayu, Ratri. 2016. Peningkatan Karakter Tanggung Jawab Siswa SD Melalui Penilaian Produk Pada pembelajaran Mind Mapping. Jurnal Konseling GUSJIGANG. 2(1). 97-103

Sulaiman. 2014. "Pengaruh Pemberian Penguatan (Reinforcement) Oleh Guru Terhadap Motivasi Belajar Siswa Di Kelas IV SD Nunggul Lampeuneurut Aceh Besar". Jurnal Pesona Dasar, 2 (3): $85-93$ 